\title{
Effects of Codeine, Sodium Pentothal and Different Temperature Factors on the Growth Rate Development of Chrysomya rufifacies for the Forensic Entomotoxicological Purposes
}

\section{Kapil Verma*}

M.Sc Forensic Science, Amity Institute of Forensic Sciences (AIFS), B-Block, Lower Ground Floor, Amity University, Sec-125, Noida-201303, Uttar Pradesh, India

\begin{abstract}
In the above study the growth and colonization of blow flies of species Chrysomya rufifacies (Diptera: Calliphoridae) were studied under different environmental conditions at Noida, Uttar Pradesh, India. On the basis of result it was clearly seen that a changes in temperature and humidity bring about a significant changes in growth pattern of the larval stages. In the condition with the higher temperature larva developed quickly and matured into pupa when compared to the sample grown in cooler temperature. It was also noted that fly larva grew and mature faster when they were placed under humid conditions. This study investigated the effects of drugs ethanol and cannabis on growth rates of the blowfly. Where the control sample took an average of 4 days to grow from $1^{\text {st }}$ instar to pupae stages, the samples grown in the presence of ethanol and cannabis showed a much faster growth rates. Therefore it can be concluded that both the studies that were put forward before the start of this study have been proven and that the differences in environmental conditions and presence of drugs affect the growth and colonization of blow flies. This study demonstrates again the necessity of considering the possible effects of drugs in tissues on insect growth rates when estimating the postmortem interval (PMI) using entomological techniques.
\end{abstract}

Keywords: Blow fly; Larval stages; Ethanol; Cannabis; Control sample; Instars; Pupae stages; Colonization; Effect of drugs, PMI; Entomological techniques

\section{Introduction}

Forensic Entomology is the use of insects and other arthropods in forensic investigation concerning decomposed bodies and it has become the "gold standard" for estimating time since death in many countries. In addition to estimating the post-mortem interval (PMI) insects that feed on carcasses may also represent a reliable specimen for toxicological analyses (Entomotoxicology) [1-3]. It is very useful for cases where the body has been long dead. Different Species of insects lay eggs on dead compost, Forensic entomologists done research on this kind of insects and their larval lifecycles finally they determine the body has been dead before three days or four days ago. After three days of investigation, insect evidence is most accurate in some method of determining duration time since death. Recently, I have also analyzed this kind of cases' in which duration time since death was only a few hours previous to discovery [4-6].

Two main ways of using insects to determine duration time since death, by using succession ally waves of insects, using maggot age and its development in three different methods as follows, The first method is used when the corpse has been dead for between a month up to a year or more, and the second method is used when death occurred less than a month prior to discovery [7-10].

\section{Materials and Methods}

Entomology kit; Insects net, Collecting vials, Larval forceps ,Wide mouth bottles, Plastic containers and plastics specimen cups, Thermometer for measuring tem, Chamber, Camera, Preserving solution, Disposable gloves, Dropper and pipettes, Shipping containers, Vermiculite, Ruler/tape, Log book [11-14].

1. These samples were collected randomly from the meat shops. Meat kept in open environment in Noida and was subjected for collection.
2. The sample flies collected were subjected for collection and rearing of flies.

3. These flies were identified as Chrysomya rufifacies.

4. 50 flies were used in this study, placed in 12 jars (4 each) These flies were allowed to rear under different environmental conditions and different drugs ethanol, and cannabis.

5. Vermiculite was filled in rearing chamber.

6. 12 jars placed to observe the colonization of the blow flies.

7. Meats were placed inside the jars treated with drugs.

8. 8 jars were placed in 4 different environmental conditions contained meat that had been treated with different drugs.

9. 4 flies were transferred into each jar.

10. Jars were placed under the different conditions;

- $\quad$ Cool temperature (Humid) $20-24^{\circ} \mathrm{C}$

- Cool temperature (Dry) $18-22^{\circ} \mathrm{C}$

- $\quad$ Room temperature (Humid) $26-30^{\circ} \mathrm{C}$

- $\quad$ Room temperature (Dry) $24-28^{\circ} \mathrm{C}$

*Corresponding author: Kapil Verma, M.Sc Forensic Science, Amity Institute of Forensic Sciences (AIFS), B-Block, Lower Ground Floor, Amity University, Sec125, Noida-201303, Uttar Pradesh, India, E-mail: forensic.kapilalert@gmail.com

Received January 10, 2013; Accepted February 25, 2013; Published February 28, 2013

Citation: Verma K (2013) Effects of Codeine, Sodium Pentothal and Different Temperature Factors on the Growth Rate Development of Chrysomya rufifacies for the Forensic Entomotoxicological Purposes. J Bioanal Biomed 5: 006-012. doi:10.4172/1948-593X.1000074

Copyright: (c) 2013 Verma K. This is an open-access article distributed under the terms of the Creative Commons Attribution License, which permits unrestricted use, distribution, and reproduction in any medium, provided the original author and source are credited. 
Citation: Verma K (2013) Effects of Codeine, Sodium Pentothal and Different Temperature Factors on the Growth Rate Development of Chrysomya rufifacies for the Forensic Entomotoxicological Purposes. J Bioanal Biomed 5: 006-012. doi:10.4172/1948-593X.1000074

11. All the observation were noted /recorded day by day.

12. From the point of $1^{\text {st }}$ appearance of larva, closely counts of larva/pupa were made time to time until all larvae had reached the pupa stage.

\section{Results}

\section{Control sample}

Condition: Room temperature (Dry): The jar containing adult blow flies were placed at room temperature on the $11^{\text {th }}$ march. The eggs were observed to have been laid by the $14^{\text {th }}$ march. On the $3^{\text {rd }}$ day after incubation the $1^{\text {st }}$ in star stage was observed. From which point counting was performed after 6 hour. By the $78^{\text {th }}$ hour, the counting was made of a mixture of a larva and pupa and the final reading taken at 90 hours was of the pupa (Tables 1 and 2).

\section{Control sample}

Condition: Room temperature (Humid): The jar containing

\begin{tabular}{|c|c|}
\hline Date of observation & Observation \\
\hline $11^{\text {th }}$ March & 4 flies placed in jars \\
\hline $12^{\text {th }}$ & No activity \\
\hline $13^{\text {th }}$ & 1 fly dead \\
\hline $14^{\text {th }}$ & 2 fly dead, eggs laid \\
\hline $15^{\text {th }}$ & 1 fly dead, $1^{\text {st }}$ instar, $(2 \mathrm{~mm})$ \\
\hline $16^{\text {th }}$ & $2^{\text {nd }}$ instar $(9 \mathrm{~mm})$ \\
\hline $17^{\text {th }}$ & $3^{\text {rd }}$ instar $(16 \mathrm{~mm})$ \\
\hline $18^{\text {th }}$ & pupae \\
\hline
\end{tabular}

Table 1: It shows observation day wise of the jar containing the flies placed for copulation.

\begin{tabular}{|c|c|}
\hline Hours & No. of larvae/pupae \\
\hline 6 & 23 \\
\hline 12 & 39 \\
\hline 18 & 50 \\
\hline 24 & 65 \\
\hline 30 & 70 \\
\hline 36 & 74 \\
\hline 42 & 79 \\
\hline 48 & 81 \\
\hline 54 & 83 \\
\hline 60 & 85 \\
\hline 66 & 85 \\
\hline 72 & 86 (larvae/pupae) \\
\hline 78 & 88 (larvae/pupae) \\
\hline 84 & 91 (pupae) \\
\hline 90 & \\
\hline
\end{tabular}

Table 2: Count of larvae taken every 6 hours after first appearance larvae $\left(15^{\text {th }}\right.$ march).

\begin{tabular}{|c|c|}
\hline Date of observation & Observation \\
\hline $26^{\text {th }}$ March & 4 flies placed in jars \\
\hline $27^{\text {th }}$ & No activity, 1 adult fly dead \\
\hline $28^{\text {th }}$ & 2 fly dead, eggs laid \\
\hline $29^{\text {th }}$ & 1 fly dead, $1^{\text {st }}$ instar $(2 \mathrm{~mm})$ \\
\hline $30^{\text {th }}$ & $2^{\text {nd }}$ instar $(7 \mathrm{~mm})$ \\
\hline $31^{\text {st }}$ & $3^{\text {rd }}$ instar $(16 \mathrm{~mm})$ \\
\hline $1^{\text {st }}$ April & pupae \\
\hline
\end{tabular}

Table 3: Observation day wise of the jar containing the flies placed for copulation.

\begin{tabular}{|c|c|}
\hline Hours & No. of larvae/pupae \\
\hline 6 & 32 \\
\hline 12 & 43 \\
\hline 18 & 56 \\
\hline 24 & 66 \\
\hline 30 & 72 \\
\hline 36 & 78 \\
\hline 42 & 82 \\
\hline 48 & 86 \\
\hline 54 & 89 \\
\hline 60 & 91 \\
\hline 66 & 94 \\
\hline 72 & 95 \\
\hline 78 & 96 (larvae/pupae) \\
\hline 84 & 95 (pupae) \\
\hline
\end{tabular}

Table 4: Count of larvae taken every 6 hours after first appearance larvae $\left(29^{\text {th }}\right.$ march)

\begin{tabular}{|c|c|}
\hline Date of observation & Observation \\
\hline $26^{\text {th }}$ March & 4 adult flies placed in jars \\
\hline $27^{\text {th }}$ & No activity, 1 adult fly dead \\
\hline $28^{\text {th }}$ & No activity, 2 adult fly dead \\
\hline $29^{\text {th }}$ & No activity, 1 adult fly dead \\
\hline $30^{\text {th }}$ & Eggs laid \\
\hline $31^{\text {st }}$ & $1^{\text {st }}$ instar $(2 \mathrm{~mm})$ \\
\hline $1^{\text {st }}$ April & $2^{\text {nd }}$ instar $(7 \mathrm{~mm})$ \\
\hline $2^{\text {nd }}$ & $2^{\text {nd }}$ instar $(13 \mathrm{~mm})$ \\
\hline $3^{\text {rd }}$ & $3^{\text {rd }}$ instar $(17 \mathrm{~mm})$ \\
\hline $4^{\text {th }}$ & pupae \\
\hline
\end{tabular}

Table 5: Observation day wise of the jar containing the flies placed for copulation.

\begin{tabular}{|c|c|}
\hline Hours & No. of larvae/pupae \\
\hline 6 & 14 \\
\hline 12 & 26 \\
\hline 18 & 35 \\
\hline 24 & 43 \\
\hline 30 & 49 \\
\hline 36 & 56 \\
\hline 42 & 63 \\
\hline 48 & 66 \\
\hline 54 & 68 \\
\hline 60 & 71 \\
\hline 66 & 72 \\
\hline 72 & 73 \\
\hline 78 & 71 \\
\hline 84 & 71 \\
\hline 90 & 68 (larvae/pupae) \\
\hline 96 & 67 (larvae/pupae) \\
\hline 102 & 65 (pupae) \\
\hline
\end{tabular}

Table 6: Count of larvae taken every 6 hours after first appearance larvae (31 march).

adult blow flies were placed at room temperature on the $26^{\text {th }}$ march On the $4^{\text {th }}$ day after incubation the $1^{\text {st }}$ instar stage of larvae were observed. From which point counting was performed after 6 hour. By the $78^{\text {th }}$ hour, the counting was made of a mixture of a larva and pupa and the final reading taken at 84 hours was of the pupa (Tables 3 and 4$)$. 
Citation: Verma K (2013) Effects of Codeine, Sodium Pentothal and Different Temperature Factors on the Growth Rate Development of Chrysomya rufifacies for the Forensic Entomotoxicological Purposes. J Bioanal Biomed 5: 006-012. doi:10.4172/1948-593X.1000074

\begin{tabular}{|c|c|}
\hline Date of observation & Observation \\
\hline $26^{\text {th }}$ March & 4 flies placed in jars, 1 fly dead \\
\hline $27^{\text {th }}$ & No activity, 2 fly dead \\
\hline $28^{\text {th }}$ & No activity, 1 fly dead \\
\hline $29^{\text {th }}$ & No activity, \\
\hline $30^{\text {th }}$ & Eggs laid \\
\hline $31^{\text {st }}$ & $1^{\text {st }}$ instar $(3 \mathrm{~mm})$ \\
\hline $1^{\text {st }}$ April & $2^{\text {nd }}$ instar $(9 \mathrm{~mm})$ \\
\hline $2^{\text {nd }}$ & $2^{\text {nd }}$ instar $(14 \mathrm{~mm})$ \\
\hline $3^{\text {rd }}$ & $3^{\text {rd }}$ instar $(17 \mathrm{~mm})$ \\
\hline $4^{\text {th }}$ & pupae \\
\hline
\end{tabular}

Table 7: Observation day wise of the jar containing the flies placed for copulation.

\begin{tabular}{|c|c|}
\hline Hours & No. of larvae/pupae \\
\hline 6 & 19 \\
\hline 12 & 32 \\
\hline 18 & 47 \\
\hline 24 & 53 \\
\hline 30 & 61 \\
\hline 36 & 65 \\
\hline 42 & 70 \\
\hline 48 & 74 \\
\hline 54 & 76 \\
\hline 60 & 77 \\
\hline 66 & 78 \\
\hline 72 & 78 \\
\hline 78 & 77 (larvae/pupae) \\
\hline 84 & 76 (larvae/pupae) \\
\hline 90 & 74 (pupae) \\
\hline 96 & \\
\hline
\end{tabular}

Table 8: Count of larvae taken every 6 hours after first appearance larvae $31^{\text {st }}$ March.

\section{Control sample}

Condition: Room temperature (Dry): The jar containing adult blow flies were placed at room temperature on the $26^{\text {th }}$ march. The eggs were observed to have been laid by the $30^{\text {th }}$ march. On the $6^{\text {th }}$ day after incubation the $1^{\text {st }}$ instar stage of larvae were observed. From which point counting was performed after 6 hour. By the $90^{\text {th }}$ hour, the counting was made of a mixture of a larva and pupa and the final reading taken at 102 hours was of the pupa (Tables 5 and 6).

\section{Control sample}

Condition: Room temperature (Humid): The jar containing adult blow flies were placed at room temperature on the $26^{\text {th }}$ march. On the $6^{\text {th }}$ day after incubation the $1^{\text {st }}$ instar stage of larvae were observed. The $1^{\text {st }}$ instar stages of larvae were first observed on the $31^{\text {th }}$ march. From which point counting was performed after 6 hour. By the $84^{\text {th }}$ hour, the counting was made of a mixture of a larva and pupa and the final reading taken at 96 hours was of the pupa (Tables 7 and 8 ).

\section{Ethanol treated sample}

Condition: Room temperature (Dry): The jar containing adult blow flies were placed at room temperature on the $15^{\text {th }}$ march. The eggs were observed to have been laid by the $17^{\text {th }}$ march. On the $4^{\text {th }}$ day $\left(18^{\text {th }}\right.$ march) after incubation the $1^{\text {st }}$ instar stage of larvae were observed. From which point counting was performed after 6 hour. By the $66^{\text {th }}$ hour, the counting was made of a mixture of a larva and pupa and the final reading taken at 72 hours was of the pupa (Tables 9 and 10).

\section{Ethanol treated sample}

Condition: Room temperature (Humid): The jar containing adult blow flies were placed at room temperature on the $26^{\text {th }}$ march. The eggs were observed to have been laid by the $28^{\text {th }}$ march. On the $5^{\text {th }}$ day $\left(30^{\text {th }}\right.$ march) after incubation the $1^{\text {st }}$ instar stage of larvae were observed. From which point counting was performed after 6 hour. By the $54^{\text {th }}$ hour, the counting was made of a mixture of a larva and pupa and the final reading taken at 66 hours ( $2^{\text {nd }}$ April) was of the pupa (Tables 11 and 12).

\section{Ethanol treated sample}

Condition: Cool temperature (Dry): The jar containing adult blow

\begin{tabular}{|c|c|}
\hline Date of observation & Observation \\
\hline $15^{\text {th }}$ March & 4 flies placed in jars \\
\hline $16^{\text {th }}$ & No activity, 2 flies dead \\
\hline $17^{\text {th }}$ & No activity, 2 flies dead, eggs laid \\
\hline $18^{\text {th }}$ & $1^{\text {st }}$ instar, $(2 \mathrm{~mm})$ \\
\hline $19^{\text {th }}$ & $2^{\text {nd }}$ instar, $(7 \mathrm{~mm})$ \\
\hline $20^{\text {th }}$ & $2^{\text {nd }}$ instar, $(11 \mathrm{~mm})$ \\
\hline $21^{\text {st }}$ & $3^{\text {rd }}$ instar, $(16 \mathrm{~mm})$ \\
\hline $22^{\text {nd }}$ & pupae \\
\hline
\end{tabular}

Table 9: Observation day wise of the jar containing the flies placed for copulation

\begin{tabular}{|c|c|}
\hline Hours & No. of Larvae/pupae \\
\hline 6 & 18 \\
\hline 12 & 30 \\
\hline 18 & 42 \\
\hline 24 & 59 \\
\hline 30 & 68 \\
\hline 36 & 71 \\
\hline 42 & 76 \\
\hline 48 & 80 \\
\hline 54 & 82 \\
\hline 60 & 84 \\
\hline 66 & 85 \\
\hline 72 & 87 \\
\hline 78 & 88 (larvae/ pupae) \\
\hline 84 & 89 (larvae/ pupae) \\
\hline 90 & 88 (larvae/ pupae) \\
\hline 96 & 88 (larvae/ pupae) \\
\hline 102 & 87 (larvae/ pupae) \\
\hline 108 & 87 (larvae/ pupae) \\
\hline 114 & 87 pupae \\
\hline
\end{tabular}

Table 10: Count of larvae taken every 6 hours after first appearance larvae $18^{\text {th }}$ march.

\begin{tabular}{|c|c|}
\hline Date of observation & Observation \\
\hline $26^{\text {th }}$ March & 4 flies placed in jars \\
\hline $27^{\text {th }}$ & No activity, 1 fly dead \\
\hline $28^{\text {th }}$ & 3 flies dead, eggs laid \\
\hline $29^{\text {th }}$ & No activity \\
\hline $30^{\text {th }}$ & $1^{\text {st }}$ instar, $(1 \mathrm{~mm})$ \\
\hline $31^{\text {st }}$ & $1^{\text {st }}$ instar, $(4 \mathrm{~mm})$ \\
\hline $1^{\text {st }}$ April & $2^{\text {nd }}$ instar, $(9 \mathrm{~mm})$ \\
\hline $2^{\text {nd }}$ & $3^{\text {rd }}$ instar, $(13 \mathrm{~mm})$ \\
\hline $3^{\text {rd }}$ & $3^{\text {rd }}$ instar, $(17 \mathrm{~mm})$ \\
\hline $4^{\text {th }}$ & pupae \\
\hline
\end{tabular}

Table 11: Observation day wise of the jar containing the flies placed for copulation 
Citation: Verma K (2013) Effects of Codeine, Sodium Pentothal and Different Temperature Factors on the Growth Rate Development of Chrysomya rufifacies for the Forensic Entomotoxicological Purposes. J Bioanal Biomed 5: 006-012. doi:10.4172/1948-593X.1000074

\begin{tabular}{|c|c|}
\hline Hours & No. of Larvae/pupae \\
\hline 6 & 31 \\
\hline 12 & 42 \\
\hline 18 & 54 \\
\hline 24 & 67 \\
\hline 30 & 73 \\
\hline 36 & 79 \\
\hline 42 & 83 \\
\hline 48 & 85 \\
\hline 54 & 87 \\
\hline 60 & 88 \\
\hline 66 & 91 \\
\hline 72 & 93 (larvae/ pupae) \\
\hline 78 & 95 (larvae/ pupae) \\
\hline 84 & 96 (larvae/ pupae) \\
\hline 90 & 96 (larvae/ pupae) \\
\hline 96 & 95 (larvae/ pupae) \\
\hline 102 & 95 (larvae/ pupae) \\
\hline 108 & 94 (pupae) \\
\hline & \\
\hline & \\
\hline
\end{tabular}

Table 12: Count of larvae taken every 6 hours after first appearance larvae $30^{\text {th }}$ march.

\begin{tabular}{|c|c|}
\hline Date of observation & Observation \\
\hline $26^{\text {th }}$ March & 4 flies placed in jar \\
\hline $27^{\text {th }}$ & No activity, 2 fly dead \\
\hline $28^{\text {th }}$ & No activity 2 flies dead \\
\hline $29^{\text {th }}$ & Eggs laid \\
\hline $30^{\text {th }}$ & No activity \\
\hline $31^{\text {st }}$ & No activity \\
\hline $1^{\text {st }}$ & $1^{\text {st }}$ instar, $(3 \mathrm{~mm})$ \\
\hline $2^{\text {nd }}$ & $2^{\text {nd }}$ instar $(8 \mathrm{~mm})$ \\
\hline $3^{\text {rd }}$ & $2^{\text {instar }(11 \mathrm{~mm})}$ \\
\hline $4^{\text {th }}$ & $3^{\text {rd }}$ instar $(16 \mathrm{~mm})$ \\
\hline $5^{\text {th }}$ & pupae \\
\hline
\end{tabular}

Table 13: Observation day wise of the jar containing the flies placed for copulation.

flies were placed at room temperature on the $26^{\text {th }}$ march. On the $4^{\text {th }}$ day $\left(29^{\text {th }}\right.$ march) after incubation the $1^{\text {st }}$ instar stage of larvae were observed. From which point counting was performed after 6 hour. By the $66^{\text {th }}$ hour, the counting was made of a mixture of a larva and pupa and the final reading taken at 84 hours was of the pupa (Tables 13 and 14).

\section{Ethanol treated sample}

Condition: Cool temperature (Humid): The jar containing adult blow flies were placed at room temperature on the $26^{\text {th }}$ march. The eggs were observed to have been laid by the $29^{\text {th }}$ march. On the $5^{\text {th }}$ day $\left(30^{\text {th }}\right.$ march) after incubation, the $1^{\text {st }}$ in star stage of larvae were observed. From which point counting was performed after 6 hour. By the $54^{\text {th }}$ hour, the counting was made of a mixture of a larva and pupa and the final reading taken at 66 hours was of the pupa (Tables 15 and 16).

\section{Cannabis treated sample}

Condition: Room temperature (Dry): The jar containing adult blow flies were placed at room temperature on the $15^{\text {th }}$ march. The eggs were observed to have been laid by the $17^{\text {th }}$ march. On the $4^{\text {th }}$ day $\left(18^{\text {th }}\right.$ march) after incubation the $1^{\text {st }}$ instar stage of larvae were observed. From which point counting was performed after 6 hour. By the $72^{\text {th }}$ hour, the counting was made of a mixture of a larva and pupa and the final reading taken at $78^{\text {th }}$ hours was of the pupa (Tables 17 and 18).

\begin{tabular}{|c|c|}
\hline Hours & No. of Larvae / pupae \\
\hline 6 & 4 \\
\hline 12 & 13 \\
\hline 18 & 23 \\
\hline 24 & 32 \\
\hline 30 & 40 \\
\hline 36 & 46 \\
\hline 42 & 54 \\
\hline 48 & 58 \\
\hline 54 & 62 \\
\hline 60 & 63 \\
\hline 66 & 64 \\
\hline 72 & 66 \\
\hline 78 & 67 \\
\hline 84 & 67 (larvae/ pupae) \\
\hline 90 & 68 (larvae/ pupae) \\
\hline 96 & 67 (larvae/ pupae) \\
\hline 102 & 67 (larvae/ pupae) \\
\hline 108 & 66 (larvae/ pupae) \\
\hline 114 & 64 (larvae/ pupae) \\
\hline 120 & 63 pupae \\
\hline
\end{tabular}

Table 14: Count of larvae taken every 6 hours after first appearance larvae $1^{\text {st }}$ april.

\begin{tabular}{|c|c|}
\hline Date of observation & Observation \\
\hline $26^{\text {th }}$ March & 4 flies placed in jar \\
\hline $27^{\text {th }}$ & No activity, 1fly dead \\
\hline $28^{\text {th }}$ & Eggs Laid, 3 flies dead \\
\hline $29^{\text {th }}$ & No activity \\
\hline $30^{\text {th }}$ & $1^{\text {st }}$ in star, $(2 \mathrm{~mm})$ \\
\hline $31^{\text {st }}$ & $1^{\text {st }}$ in star, $(5 \mathrm{~mm})$ \\
\hline $1^{\text {st }}$ & $2^{\text {nd }}$ instar $(9 \mathrm{~mm})$ \\
\hline $2^{\text {nd }}$ & $2^{\text {nd }}$ instar $(11 \mathrm{~mm})$ \\
\hline $3^{\text {rd }}$ & $3^{\text {rd }}$ instar $(15 \mathrm{~mm})$ \\
\hline $4^{\text {th }}$ & pupae \\
\hline
\end{tabular}

Table 15: Observation day wise of the jar containing the flies placed for copulation.

\begin{tabular}{|c|c|}
\hline Hours & No. of Larvae/pupae \\
\hline 6 & 5 \\
\hline 12 & 18 \\
\hline 18 & 27 \\
\hline 24 & 38 \\
\hline 30 & 45 \\
\hline 36 & 55 \\
\hline 42 & 62 \\
\hline 48 & 64 \\
\hline 54 & 66 \\
\hline 60 & 68 \\
\hline 66 & 72 \\
\hline 72 & 74 \\
\hline 78 & 75 \\
\hline 84 & 74 (larvae/ pupae) \\
\hline 90 & 74 (larvae/ pupae) \\
\hline 96 & 73 (larvae/ pupae) \\
\hline 102 & 72 (larvae/ pupae) \\
\hline 108 & 72 (larvae/ pupae) \\
\hline 114 & 71 (larvae/ pupae) \\
\hline 120 & 71 (pupae) \\
\hline
\end{tabular}

Table 16: Count of larvae taken every 6 hours after first appearance larvae $30^{\text {th }}$ march. 
Citation: Verma K (2013) Effects of Codeine, Sodium Pentothal and Different Temperature Factors on the Growth Rate Development of Chrysomya rufifacies for the Forensic Entomotoxicological Purposes. J Bioanal Biomed 5: 006-012. doi:10.4172/1948-593X.1000074

\section{Cannabis treated sample}

Condition: Room temperature (Humid): The jar containing adult blow flies were placed at room temperature on the $26^{\text {th }}$ march. The eggs were observed to have been laid by the $28^{\text {th }}$ march. On the $4^{\text {th }}$ day $\left(29^{\text {th }}\right.$ march) after incubation the $1^{\text {st }}$ instar stage of larvae were observed. From which point counting was performed after 6 hour. By the $60^{\text {th }}$ hour, the counting was made of a mixture of a larva and pupa and the final reading taken at 72 hours was of the pupa (Tables 19 and 20).

\section{Cannabis treated sample}

Condition: Cool temperature (Dry): The jar containing adult blow flies were placed at room temperature on the $26^{\text {th }}$ march. The eggs were observed to have been laid by the $29^{\text {th }}$ march. On the $4^{\text {th }}$ day $\left(30^{\text {th }}\right.$ march) after incubation the $1^{\text {st }}$ instar stage of larvae were observed. From which point counting was performed after 6 hour. By the $72^{\text {th }}$ hour, the counting was made of a mixture of a larva and pupa and the final reading taken at 84 hours was of the pupa (Tables 21 and 22).

\section{Cannabis treated sample}

Condition: Cool temperature (Humid): The jar containing adult blow flies were placed at room temperature on the $2^{\text {nd }}$ April. The eggs were observed to have been laid by the $5^{\text {th }}$ April. On the $5^{\text {th }}$ day $\left(6^{\text {th }}\right.$ April) after incubation the $1^{\text {st }}$ instar stage of larvae were observed. From which point counting was performed after 6 hour. By the $66^{\text {th }}$ hour, the counting was made of a mixture of a larva and pupa and the final reading taken at 72 hours was of the pupa (Tables 23 and 24).

\begin{tabular}{|c|c|}
\hline Date of observation & Observation \\
\hline $28^{\text {th }}$ March & 4 flies placed in jars, 1 fly dead \\
\hline $29^{\text {th }}$ & No activity, 1 fly dead \\
\hline $30^{\text {th }}$ & No activity, 2 flies dead, eggs laid \\
\hline $31^{\text {st }}$ & No activity \\
\hline $1^{\text {st }}$ April & $1^{\text {st }}$ instar, $(2 \mathrm{~mm})$ \\
\hline $2^{\text {nd }}$ & $2^{\text {nd }}$ instar, $(9 \mathrm{~mm})$ \\
\hline $3^{\text {rd }}$ & $2^{\text {nd }}$ instar $(12 \mathrm{~mm})$ \\
\hline $4^{\text {th }}$ & $3^{\text {rd }}$ instar $(16 \mathrm{~mm})$ \\
\hline $5^{\text {th }}$ & pupae \\
\hline
\end{tabular}

Table 17: Observation day wise of the jar containing the flies placed for copulation.

\begin{tabular}{|c|c|}
\hline Hours & No. of Larvae/pupae \\
\hline 6 & 13 \\
\hline 12 & 26 \\
\hline 18 & 38 \\
\hline 24 & 47 \\
\hline 30 & 55 \\
\hline 36 & 63 \\
\hline 42 & 65 \\
\hline 48 & 66 \\
\hline 54 & 69 \\
\hline 60 & 71 \\
\hline 66 & 73 \\
\hline 72 & 76 \\
\hline 78 & 77 \\
\hline 84 & 77 (larvae/ pupae) \\
\hline 90 & 78 (larvae/ pupae) \\
\hline 96 & 78 (larvae/ pupae) \\
\hline 102 & 79 pupae \\
\hline
\end{tabular}

Table 18: Count of larvae taken every 6 hours after first appearance larvae $1^{\text {st }}$ april.

\begin{tabular}{|c|c|}
\hline Date of observation & Observation \\
\hline $28^{\text {th }}$ March & 4 flies placed in jars, 1 fly dead \\
\hline $29^{\text {th }}$ & No activity, 2 fly dead \\
\hline $30^{\text {th }}$ & No activity, 1 fly dead, \\
\hline $31^{\text {st }}$ & eggs laid, $1^{\text {st }}$ instar, $(2 \mathrm{~mm})$ \\
\hline $1^{\text {st }}$ April & $2^{\text {nd }}$ instar, $(9 \mathrm{~mm})$ \\
\hline $2^{\text {nd }}$ & $2^{\text {nd }}$ instar, $(13 \mathrm{~mm})$ \\
\hline $3^{\text {rd }}$ & $3^{\text {rd }}$ instar, $(17 \mathrm{~mm})$ \\
\hline $4^{\text {th }}$ & Pupae \\
\hline
\end{tabular}

Table 19: Observation day wise of the jar containing the flies placed for copulation.

\begin{tabular}{|c|c|}
\hline Hours & No. of Larvae/pupae \\
\hline 6 & 24 \\
\hline 12 & 38 \\
\hline 18 & 49 \\
\hline 24 & 57 \\
\hline 30 & 63 \\
\hline 36 & 68 \\
\hline 42 & 74 \\
\hline 48 & 76 \\
\hline 54 & 79 \\
\hline 60 & 80 \\
\hline 66 & 83 \\
\hline 72 & 85 \\
\hline 78 & 84 (larvae/ pupae) \\
\hline 84 & 83 pupae \\
\hline 90 & \\
\hline
\end{tabular}

Table 20: Count of larvae taken every 6 hours after first appearance larvae $31^{\text {st }}$ march.

\begin{tabular}{|c|c|}
\hline Date of observation & Observation \\
\hline $28^{\text {th }}$ March & 4 flies placed in jars, 2 flies dead \\
\hline $29^{\text {th }}$ & no activity, 2 fly dead \\
\hline $30^{\text {th }}$ & No activity \\
\hline $31^{\text {st }}$ & eggs laid \\
\hline $1^{\text {st }}$ April & $1^{\text {st instar, }(2 \mathrm{~mm})}$ \\
\hline $2^{\text {nd }}$ & $2^{\text {nd }}$ instar, $(8 \mathrm{~mm})$ \\
\hline $3^{\text {rd }}$ & $2^{\text {nd }}$ instar, $(12 \mathrm{~mm})$ \\
\hline $4^{\text {th }}$ & $3^{\text {rd }}$ instar $(17 \mathrm{~mm})$ \\
\hline $5^{\text {th }}$ & pupae \\
\hline
\end{tabular}

Table 21: Observation day wise of the jar containing the flies placed for copulation.

\section{Discussion and Conclusion}

In the above study the growth and colonization of blow flies of species Chrysomya rufifacies were studied under different conditions. On the basis of result it was clearly seen that a changes in temperature and humidity bring about a significant changes in growth pattern of the larval stages.

In the condition with the higher temperature larva developed quickly and matured into pupa when compared to the sample grown in cooler temperature. It was also noted that fly larva grew and mature faster when they were placed under humid conditions [15-17].

When the effects of the toxins on the growth rates were observed, a clearly distinct change was seen in the growth pattern. Where the control sample took an average of 4 days to grow from $1^{\text {st }}$ instar to pupae stages, the samples grown in the presence of ethanol and cannabis showed a much faster growth rates. 
Citation: Verma K (2013) Effects of Codeine, Sodium Pentothal and Different Temperature Factors on the Growth Rate Development of Chrysomya rufifacies for the Forensic Entomotoxicological Purposes. J Bioanal Biomed 5: 006-012. doi:10.4172/1948-593X.1000074

\begin{tabular}{|c|c|}
\hline Hours & No. of Larvae/pupae \\
\hline 6 & 8 \\
\hline 12 & 14 \\
\hline 18 & 25 \\
\hline 24 & 33 \\
\hline 30 & 39 \\
\hline 36 & 45 \\
\hline 42 & 50 \\
\hline 48 & 56 \\
\hline 54 & 61 \\
\hline 60 & 64 \\
\hline 66 & 67 \\
\hline 72 & 68 \\
\hline 78 & 69 \\
\hline 84 & 70 \\
\hline 90 & 69 (larvae/ pupae) \\
\hline 96 & 68 (larvae/ pupae) \\
\hline 102 & 67 (larvae/ pupae) \\
\hline 108 & 66 pupae \\
\hline
\end{tabular}

Table 22: Count of larvae taken every 6 hrs after first appearance larvae $1^{\text {th }}$ april.

\begin{tabular}{|c|c|}
\hline Date of observation & Observation \\
\hline $28^{\text {th }}$ March & 4 flies placed in jars, 2 flies dead \\
\hline $29^{\text {th }}$ & No activity, 2 adult fly dead \\
\hline $30^{\text {th }}$ & No activity \\
\hline $31^{\text {st }}$ & eggs laid \\
\hline $1^{\text {st }}$ April & $1^{\text {st }}$ instar $(2 \mathrm{~mm})$ \\
\hline $2^{\text {nd }}$ & $2^{\text {nd }}$ instar $(8 \mathrm{~mm})$ \\
\hline $3^{\text {rd }}$ & $3^{\text {rd }}$ instar $(17 \mathrm{~mm})$ \\
\hline $4^{\text {th }}$ & pupae \\
\hline
\end{tabular}

Table 23: Observation day wise of the jar containing the flies placed for copulation

\begin{tabular}{|c|c|}
\hline Hours & No. of Larvae/pupae \\
\hline 6 & 5 \\
\hline 12 & 16 \\
\hline 18 & 26 \\
\hline 24 & 37 \\
\hline 30 & 43 \\
\hline 36 & 50 \\
\hline 42 & 55 \\
\hline 48 & 60 \\
\hline 54 & 65 \\
\hline 60 & 68 \\
\hline 66 & 70 \\
\hline 72 & 72 (larvae/ pupae) \\
\hline 78 & 73 (larvae/ pupae) \\
\hline 84 & 74 (larvae/ pupae) \\
\hline 90 & 74 (pupae) \\
\hline 96 & \\
\hline
\end{tabular}

Table 24: Count of larvae taken every 6 hours after first appearance larvae $1^{\text {st }}$ april.

The number of larvae observed also showed significant differences with the maximum reproduction occurring with the control sample, followed by the cannabis and ethanol showing the least number of larvae [18-23].

Therefore it can be concluded that both the studies that were put forward before the start of this study have been proven and that the differences in environmental conditions and presence of drugs affect the

growth and colonization of blow flies [24,25]. This study demonstrates again the necessity of considering the possible effects of drugs in tissues on insect growth rates when estimating the postmortem interval (PMI) using entomological techniques.

\section{References}

1. Byrd JH, Butler JF (1998) Effects of temperature on Chrysomya rufifacies (Diptera: Calliphoridae) development. J Med Entomol 34: 353-358.

2. Baumgartner DL (1986) The hairy maggot blow fly Chrysomya rufifacies (Macquart) confirmed in Arizona. Journal of Entomological Science 21: $130-132$

3. Byrd JH (1995) The effects of temperature on flies of forensic importance. M.S. thesis. University of Florida 197.

4. Baumgartner DL (1993) Review of Chrysomya rufifacies (Diptera: Calliphoridae) J Med Entomol 30: 338-352.

5. Catts EP (1992) Problems in estimating the postmortem interval in death investigations. Journal of Agricultural Entomology 9: 245-255.

6. Corry JEL (1978) Possible sources of ethanol ante- and post-mortem: Its relationship to the biochemistry and microbiology of decomposition. Journal of Applied Bacteriology 44: 1-56.

7. Commack JA, Nelder MP (2010) Cool-weather activity of the forensically important hairy maggot blow fly Chrysomya rufifacies (Macquart) (Diptera: Calliphoridae) on carrion in Upstate South Carolina, United States. Forensic Sci Int 195: 139-142.

8. Davies L, Radcliffe GG (1994) Development rates of some pre-adult stages in blowflies with reference to low temperature. Med Vet Entomol 8: 245-254.

9. Davis GL, Leffert RL, Rantanen NW (1972) Putrefactive ethanol sources in post-mortem tissues of conventional and germ free mice. Arch Pathol 94: 71 74.

10. Deonier CC (1940) Carcass temperatures and their relation to winter blowfly populations and activity in the southwest. Journal of Economic Entomology 33 : 166-170.

11. Monthei DR (2009) Entomotoxicological and Thermal Factors Affecting the Development of Forensically Important Flies, Faculty of Virginia Polytechnic Institute, Blacksburg 1-112.

12. Figarola JLM, Skoda SR (1998) Chrysomya rufifacies (Macquart) (Diptera: Calliphoridae) in Nebraska. J Entomol Sci 33: 319-321.

13. Goodbrod JR, Goff ML (1990) Effects of larval population density on rates of development and interactions between two species of Chrysomya (Diptera: Calliphoridae) in laboratory culture. J Med Entomol 27: 338-343.

14. Goff ML, Lord WD (1994) Entomotoxicology: a new area for forensic investigation. Am J Forensic Med Pathol 15: 51-57.

15. Tabor KL, Fell RD, Brewster CC, Pelzer K, Behonick GS (2005) Effects of ante mortem ingestion of ethanol on insect successional patterns and development of Phormia Regina (Diptera: Calliphoridae). J Med Entomol 42: 481-489.

16. Kapil Verma, Reject Paul MP (2012) Assessment of Post Mortem Interval, PMI) from Forensic Entomotoxicological study on growth rates of larvae of flies 64 .

17. Meek CL, Puskarich-May C, Carlton CE (1998) New state record for the hairy maggot blow fly Chrysomya rufifacies (Macquart) Southwest Entomol 23: 373375 .

18. Roy DN, Siddons LB (1939) the life history and bionomics of Chrysomya rufifacies Macq. (Order Diptera, Family Calliphoridae). Parasitology 31: 442 447

19. Subramanian H, Mohan KR (1980) Biology of the blow flies Chrysomya megacephala, Chrysomya rufifacies, and Lucilia cuprina. Kerala Journal of Veterinary Science 11: 252-261.

20. Shiao SF, Yeh TC (2008) Larval competition of Chrysomya megacephala and Chrysomya rufifacies (Diptera: Calliphoridae): Behavio and ecological studies of two blow fly species of forensic significance. J Med Entomol 45: 785-799.

21. Sukontason K, Piangjai S, Siriwattanarungsee S, Sukontason KL (2008) Morphology and developmental rate of blowflies Chrysomya 
Citation: Verma K (2013) Effects of Codeine, Sodium Pentothal and Different Temperature Factors on the Growth Rate Development of Chrysomya rufifacies for the Forensic Entomotoxicological Purposes. J Bioanal Biomed 5: 006-012. doi:10.4172/1948-593X.1000074

megacephala and Chrysomya rufifacies in Thailand: application in forensic entomology. Parasitology Research 102: 1207-1216.

22. Van den Oever $R$ (1976) A review of the literature as to the present possibilities and limitations in estimating the time of death. Med Sci Law 16: $269-276$

23. Van Laerhoven SL (2008) Blind validation of postmortem interval estimates using developmental rates of blow flies. Forensic Sci Int 180 76-80.

24. Vargas J, Dickerson ED, Davis MP (2001) United States prescribing habits: what's going on? (Abstract). Support Care Cancer 9: 311

25. Vinogradova EB, Marchenko MI (1984) The use of temperature parameters of fly growth in the medico legal practice. Sudebno-meditsinskaya Ekspertiza 27: $16-19$ 